\title{
A Study of Mental Health and Aggression among Smart phone users and Non User college students
}

\author{
Samadhan S. Patil ${ }^{1 *}$, Ajay V. Patil ${ }^{1}$, Akash D. Mahalpure ${ }^{1}$, Vikas P.Wagh ${ }^{1}$
}

\section{ABSTRACT}

The present study aims to determine the status of Mental Health and Aggression among Smart phone users and non user college students. The sample consists of 100 subjects 50 male and 50 female college going students. Total samples selected in the age range of 20 to 25 who are living in urban area. Standardized psychological test (Mental health and aggression) was used for data collection. After doing this, the scoring data was treated as a mean, SD, t test.

Keywords: Mental Health, Aggression, Smart phone users and Non Users college students

Unfortunately, violence toward others is another form of social interaction. When one person hurts or tries to destroy another person deliberately, either with words or with physical behavior, psychologists call it aggression. One common cause of aggressive behavior is frustration, which occurs when a person is prevented from reaching some desired goal. The concept of aggression as a reaction to frustration is known as the frustration-aggression hypothesis (Berkowitz, 1993; miller et al., 1941). There are many sources of frustration that can lead to aggressive behavior. Pain, for example, produces negative sensations that are often intense an uncontrollable, leading to frustration and often aggressive acts against the nearest available target (Berkowitz, 1993). Loud noises, excessive heat, the irritation of someone else's cigarette smoke, and even awful smells can lead people to act out in an aggressive manner (Anderson, 1987; Rotton et al., 1979; Rotton \& frey, 1985; Zillmann et al., 1981)

Mental health describes a level of psychological well-being, or an absence of a mental disorder. From the perspective of 'positive psychology' or 'holism', mental health may include an individual's ability to enjoy life, and create a balance between life activities and efforts to achieve psychological resilience. Mental health can also be defined as an expression of emotions, and as signifying a successful adaptation to a range of demands.

The world health organization defines mental health as "a state of well-being in which the individual realizes his or her own abilities, can cope with the normal stresses of life, can work productively and fruitfully, and is able to make a contribution to his or her community”. It was

\footnotetext{
${ }^{1}$ M.A- II, Dept. Of Psychology, M.J.College, Jalgaon (MS) India

*Responding Author

(c) 2015 I S Patil, A Patil, A Mahalpure, V Wagh; licensee IJIP. This is an Open Access Research distributed under the terms of the Creative Commons Attribution License (http://creativecommons.org/licenses/by/2.0), which permits unrestricted use, distribution, and reproduction in any Medium, provided the original work is properly cited.
} 
previously stated that there was no one "official" definition of mental health. Mental health refers to our cognitive, and emotional well being - it is all about how we think, feel and behave. Mental health, if somebody has it.

We can see the addiction of over use of smart phones in a youth. The over use of smart phone are affect on a mental health of youth. We can see negative psychological symptoms in a youth.

\section{THE IMPORTANCE OF STUDY}

Televisions came in India in 80's. The disadvantages and it create various problems. In the 90's computer came to India with internet and other features. This is responsible for the some sort of problems. But now in 21'st century smart phone came with the combined features of T.V. and Computers. Is it portable to carry it anywhere. So the psychological and social problems multiplied due to smart phones. Developed country is already affected by this smart phone addiction and now developing countries like India are also being affected by it. On international level, we come across many psychological disorders it is a because of smart phone addiction and the big disadvantages of overuse smart phones. So it is a challenge to find some solutions on this global problem.

Problems like learning disability, becoming introvert, increasing aggression, emotional instability, and cognitive capacity lose, possessiveness, laziness, insomnia, doziness, social nonconformity occur and now some concrete solution on this problem is must. As per the global need of the subject we have chosen this problem.

\section{REVIEW OF THE STUDY}

Studies have shown that the Internet addiction is one of the major factors influencing mental and physical health. Wishart (1990) in his study showed that the dependence on the Internet has created severe gaps and breaks in academic, social, financial and occupational life of contributors. fifty-eight percent of schoolchildren and students have experienced a significant reduction in study habits, grades drop, absence in the class, and so forth. Additionally, there is no control over them to spend their time in academic activities.

Thomson (2008) in a research on the effects of the Internet addiction on the feeling of lack of suitable and actual social relations among the students showed that most of the students have recorded that their social skills are impaired. Forty-seven percent of respondents have referred to physical disorders such as vision obscurity, insomnia. Thomson in the end concludes that the phenomenon of the Internet addiction is a new one, and in fact most of the people who are already suffering, respond to freshness of this knowledge source.

Statistics show that in 2003, 88\% of the UK population aged 15 to 24 owned mobile phones (ONS 2003) and this figure continues to rise. Recent research with under $25^{\text {ee }}$ s suggests that mobile phones are instrumentally, socially and emotionally important (Green 2003). 
The body of work on „difference ${ }^{c e}$ and the intersections of ethnicity, class, gender, sexuality and age can inform our understanding of the relationship between youth identities and mobile technologies (Woodward 1997; Brah and Phoenix 2004)iii. Identity is viewed here as something that is ,in process ${ }^{e e}$, unfinished, constructed and reconstructed (Hall 1996), experienced,

The present study was planned and performed to study the Aggression and Mental Health among smart phone users and non-users students of Jalgaon district.

\section{OBJECTIVES}

- To find out the difference in aggression of male and female students.

- To find out the difference in aggression of smart phone users and non-user students.

- To find out the difference in mental health factors of male and female students.

- To find out the difference in mental health factors of smart phone users and non-user students.

\section{Hypothesis}

- There is no significant difference in aggression between the male and female students.

- There is no significant difference in aggression between the smart phone users and nonuser students.

- There is no significant difference in factors of mental health between the male and female students.

- There is no significant difference in factors of mental health between the smart phone users and non-user students.

\section{Variables}

- Independent variable -
A) Gender - 1) Male 2) Female
B) Smart phone - 1) Users 2) Non-users

- Dependent variable -
A) Aggression
B) Mental Health

\section{METHODOLOGY}

\section{Sample}

The sample of the study consists of 100 students (50 male and 50 female) Sample of the study was selected by simple random sampling from the college going students. Their age range was 20-25 years. Thus, the male and female student's ratio was 1:1.

\section{Tools}

Aggression - test was constructed and standardized by Dr. Guru Pyari Mathur and Dr. Raj kumara Bhatnagar. Mental Health - test was constructed and standardized by Dr. Anand Kumar and Dr. Giridhar P. Thakur. 


\section{Research Design}

Since, there were two independent variables and each variable was classified at two levels. A $2 \times 2$ factorial design was used.

\section{Statistical Treatment of Data}

First, the data was treated by means, SD and t. SPSS software (Version 17.0) was used for data analysis.

\section{RESULT AND DISCUSSION}

In this part investigator has explained the result related to statistical analysis and hypothesis.

HY-01- There is no significant difference in Aggression between the male and female students.

Table no- 01 - Gender wise comparison on aggression

\begin{tabular}{|l|l|l|l|l|l|l|}
\hline Variable & Gender & $\mathbf{N}$ & Mean & $\begin{array}{l}\text { Std. } \\
\text { Deviation }\end{array}$ & t & Sig. level \\
\hline $\begin{array}{l}\text { AGGRESSI } \\
\text { ON }\end{array}$ & Male & 50 & 187.72 & 19.75 & 2.58 & 0.05 \\
\cline { 2 - 5 } & Female & 50 & 200.90 & 30.21 & & \\
\hline
\end{tabular}

$P$ at $0-05=1.98,0.01=2.61$

Table no 01 shows the level of aggression among male and female students. The researcher found that the mean value in aggression of male students was 187.72 and SD is 19.75. Similarly the mean value in aggression of female students was 200.90 and SD is 30.21 . The calculate "t" value is 2.58. It is significant at 0.05 levels. It indicates that there is significant difference in aggression between the male and female students. That's why above hypothesis is rejected.

HY-02-. There is no significant difference in aggression between the smart phone users and nonusers students

Table no- 02 - Phone device wise comparison on Aggression

\begin{tabular}{|l|l|l|l|l|l|l|}
\hline \multirow{2}{*}{ Aggression } & $\begin{array}{l}\text { Phone } \\
\text { device }\end{array}$ & $\mathbf{N}$ & $\mathbf{M}$ & SD & t & Sig. Level \\
\cline { 2 - 7 } & $\begin{array}{l}\text { Smart } \\
\text { phone user }\end{array}$ & 50 & 191.18 & 27.86 & 1.19 & NS \\
\cline { 2 - 5 } & 50 & 197.44 & 24.39 & & \\
\hline
\end{tabular}

$P$ at $0-05=1.98,0.01=2.61$

Table no 02 show the aggression among smart phone users and non-user college students. The researcher found that the mean value in aggression of smart phone users students was 191.18 and $\mathrm{SD}$ is 27.86. Similarly the mean value in aggression of smart phone non-users students was 197.44 and SD is 24.39. The calculate "t" value is 1.19. It is no significant. It indicates that there is no significant difference in aggression between the smart phone users and non-users students. That's why above hypothesis is accepted. 
HY-03- There is no significant difference in factors of mental health between the male and female students

Table no- 03 - Gender wise comparison on factors of mental health

\begin{tabular}{|c|c|c|c|c|c|c|}
\hline $\begin{array}{l}\text { Mental } \\
\text { Health } \\
\text { Factors }\end{array}$ & Gender & $\mathbf{N}$ & Mean & Std. Deviation & $\mathbf{t}$ & Sig. level \\
\hline \multirow{2}{*}{ EG } & male & 50 & 24.2400 & 4.24533 & \multirow[t]{2}{*}{1.94} & \multirow[t]{2}{*}{ NS } \\
\hline & \begin{tabular}{|l|} 
female \\
\end{tabular} & 50 & 25.8200 & 3.86343 & & \\
\hline \multirow{2}{*}{ AL } & male & 50 & 22.8200 & 4.42022 & \multirow[t]{2}{*}{2.12} & \multirow[t]{2}{*}{0.05} \\
\hline & female & 50 & 24.8200 & 4.99669 & & \\
\hline \multirow{2}{*}{ EX } & male & 50 & 31.0600 & 4.59996 & \multirow[t]{2}{*}{2.23} & \multirow[t]{2}{*}{0.05} \\
\hline & female & 50 & 29.0800 & 4.25148 & & \\
\hline \multirow{2}{*}{ EU } & male & 50 & 24.7800 & 4.82464 & \multirow[t]{2}{*}{1.19} & \multirow[t]{2}{*}{ NS } \\
\hline & female & 50 & 25.9800 & 5.21963 & & \\
\hline \multirow{2}{*}{ SN } & male & 50 & 27.7600 & 4.46099 & \multirow[t]{2}{*}{1.29} & \multirow[t]{2}{*}{ NS } \\
\hline & \begin{tabular}{|l|} 
female \\
\end{tabular} & 50 & 28.8000 & 3.53409 & & \\
\hline
\end{tabular}

$P$ at $0-05=1.98,0.01=2.61$

Table no 03 shows the factors of mental health among male and female students. The researcher found that the mean value in Egocentrism of male students was 24.24 and SD is 4.24. Similarly the mean value in Egocentrism of female students was 25.82 and SD is 3.86. The calculated "t" value is 1.94. It is not significant. The mean value in Alienation of male students was 22.82 and SD is 4.42. Similarly the mean value in Alienation of female students was 24.82 and SD is 4.99. The calculated "t" value is 2.12. It is significant at 0.05 levels. The mean value in Expression of male students was 31.06 and SD is 4.59. Similarly the mean value in Expression of female students was 29.08 and SD is 4.25. The calculated " $\mathrm{t}$ " value is 2.23. It is significant at 0.05 levels. The mean value in Emotional Unstability of male students was 24.78 and SD is 4.82 . Similarly the mean value in Emotional Unstability of female students was 25.98 and SD is 5.21. The calculated " $\mathrm{t}$ " value is 1.19. It is not significant. The mean value in Social NonConformity of male students was 27.76 and SD is 4.46. Similarly the mean value in Social NonConformity of female students was 28.80 and SD is 3.53. The calculated " $t$ " value is 1.29. It is no significant. But Alienation and Expression factors is significant at 0.05 levels. 
HY-04 - There is no significant difference in factors of mental health between the smart phone users and non-users students.

Table no- 04 - Phone device wise comparison on Factors of Mental Health

\begin{tabular}{|c|c|c|c|c|c|c|}
\hline $\begin{array}{l}\text { Mental } \\
\text { Health } \\
\text { factors }\end{array}$ & $\begin{array}{l}\text { Phone } \\
\text { device }\end{array}$ & $\mathbf{N}$ & Mean & Std. Deviation & $\mathbf{t}$ & Sig. level \\
\hline \multirow[t]{2}{*}{ EG } & $\begin{array}{l}\text { Smart } \\
\text { phone } \\
\text { user }\end{array}$ & 50 & 24.3200 & 4.62663 & \multirow[t]{2}{*}{1.74} & \multirow[t]{2}{*}{ NS } \\
\hline & non-user & 50 & 25.7400 & 3.43339 & & \\
\hline \multirow{2}{*}{ AL } & user & 50 & 23.2400 & 4.60948 & \multirow[t]{2}{*}{1.21} & \multirow[t]{2}{*}{ NS } \\
\hline & non-user & 50 & 24.4000 & 4.96107 & & \\
\hline \multirow{2}{*}{ EX } & user & 50 & 30.2400 & 4.37787 & \multirow[t]{2}{*}{.37} & \multirow[t]{2}{*}{ NS } \\
\hline & non-user & 50 & 29.9000 & 4.69150 & & \\
\hline \multirow{2}{*}{ EU } & user & 50 & 24.2800 & 4.92408 & \multirow[t]{2}{*}{2.22} & \multirow[t]{2}{*}{0.05} \\
\hline & non-user & 50 & 26.4800 & 4.95383 & & \\
\hline \multirow{2}{*}{ SN } & user & 50 & 27.7800 & 3.99638 & \multirow[b]{2}{*}{1.24} & \multirow[t]{2}{*}{ NS } \\
\hline & non-user & 50 & 28.7800 & 4.05719 & & \\
\hline
\end{tabular}

$P$ at $0-05=1.98,0.01=2.61$

Table no 04 shows the factor of mental health among smart phone users and non-users students. The researcher found that the mean value in Egocentrism of smart phone user's students was 24.32 and SD is 4.62. Similarly the mean value in Egocentrism of smart phone non-users students was 25.74 and SD is 3.43. The calculated " $t$ " value is 1.74 . It is not significant. The mean value in Alienation of smart phone user's students was 23.24 and SD is 4.60. Similarly the mean value in Alienation of smart phone non-users students was 24.40 and SD is 4.96. The calculated " $t$ " value is 1.21. It is not significant. The mean value in Expression of smart phone user's students was 30.24 and SD is 4.37. Similarly the mean value in Expression of smart phone non-users students was 29.90 and SD is 4.69. The calculated " $t$ " value is .37. It is no significant. The mean value in Emotional unstability of smart phone user's students was 24.28 and SD is 4.92. Similarly the mean value in Emotional unstability of smart phone non-users students was 26.48 and SD is 4.95. The calculated " $\mathrm{t}$ " value is 2.22. It is significant at 0.05 levels. The mean value in Social Non-Conformity of mobile user's students was 27.78 and SD is 3.99. Similarly the mean value in Social Non-Conformity of smart phone non-users students was 28.78 and SD is 4.05. The calculated "t" value is 1.24. It is no significant. But Emotional Unstability factor is significant at 0.05 levels.

\section{DISCUSSION}

The aim of the present study was to find out the difference in aggression and mental health of college going students in Jalgaon district. 


\section{A Study of Mental Health and Aggression among Smart phone users and Non User college students}

First hypothesis result obtained after analysis of data as seen in table no-01 reveals significant difference between male and female students with reference to their aggression. This significant " $t$ " value (2.58) indicates that gender significantly affects the aggression. This reveals the fact that female students show more aggression than male students. The Female students are emotionally strong than the male So the Psychological problems like emotional unstability occurs a causes the aggression. In Indian culture females have less freedom than the male So they become more possessive of using smart phone than the male. The possession on towards mobile also causes the aggression.

Second hypothesis result obtained after analysis of the data as see in table no-02 reveals that there is no significant difference between smart phone users and non-users students with reference to their aggression. This no significant "t" value (1.19) indicates that smart phone user and non-users do not show any aggression.

Third hypothesis result obtained after analysis of the data is seen table no-03 reveals that is there is a significant difference get two factors of mental health(Alienation and Expression) and other three factors of mental health do not show significant differences(Egocentrism, Emotional Unstability and Social Non-Conformity).

There is significant differences between the male and female students with reference to their Alienation factor of mental health. This significant "t" value (2.12) indicates that gender significantly affects the Alienation factor. Studies have shown that the Internet addiction is one of the major factors influencing mental and physical health. Wishart (1990)

There is would be significant differences between the male and female students with reference to their Expression factor of mental health. This significant "t" value (2.23) indicates that gender significantly affects the Expression factor. Thomson (2008) in a research on the effects of the Internet addiction on the feeling of lack of suitable and actual social relations among the students showed that most of the students have recorded that their social skills is impaired. Forty-seven percent of respondents have referred to physical disorders such as vision obscurity, insomnia. Thomson in the end concludes that the phenomenon of the Internet addiction is a new one, and in fact most of the people who already are suffering, respond to freshness of this knowledge source. Statistics show that in 2003, 88\% of the UK population aged 15 to 24 owned mobile phones

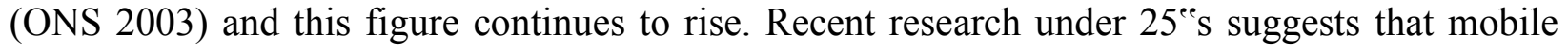
phones are instrumentally, socially and emotionally important (Green 2003).

Fourth hypothesis obtained after analysis of the data show table no-04 reveals that there is significant differences get one factors of mental health(Emotional Unstability) and other four factors of mental health show no significant differences(Egocentrism, Alienation, Expression, and Social Non-Conformity) 
There is significant difference between the smart phone users and non-users students with reference to their Emotional Unstability factor of mental health. This significant " $t$ " value (2.22) indicates that smart phone users and non-users significantly affect the Emotional Unstability factor. This reveals the fact that smart phone non-users students have high level Emotional Unstability than mobile user's students. Thomson (2008) in a research on the effects of the Internet addiction on the feeling of lack of suitable and actual social relations among the students showed that most students have recorded that their social skills are impaired. Forty-seven percent of respondents have referred to physical disorders such as vision obscurity, insomnia. Thomson in the end concludes that the phenomenon of the Internet addiction is a new one, and in fact most of the people who are already are suffering, respond to freshness of this knowledge source.

\section{CONCLUSION}

- $\quad$ Female students are more aggressive than male students.

- There is no significant difference in aggression between the smart phone users and nonusers students.

- Female students Alienation level show higher than male students and male student's expression level is high than female students.

- Smart phone non-users students' emotional unstability level of high than mobile user's students.

\section{REFERENCES}

Anderson, C.A. \& Huesmann, L.R. (2003). Human aggression: A social-cognitive view. In M.A. Hogg \& J. Cooper (Eds.), Handbook of Social Psychology (pp. 296-323). London: Sage Publications.

Baron, R.T. (1998) Social Psychology, PHI Publications.

Borude, R.R. (2005) Research Methodology. Chhya Publication, Aurangabad.

Morgan .C.T. (2001) Introduction to Psychology, Tata McGraw Hill Publications

Morgan.C.T. (2001) Introduction to Psychology, Tata Mcgraw Hill Publications.

Saundra K. Ciccarelli, Glenn E. Meyer (2015), Psychology south Asian Addition, Person Publication. 